\title{
Peasant Frontiers and the Enigma of Peasant Work
}

\author{
Eric Vanhaute
}

Keywords: peasant, peasantries, peasant question, labor, subsistence

\begin{abstract}
Peasant households produce most of the food in the world today, as they have for millennia. Concentrated in China and India, and spread across the Global South, the variegated persistence of differentiated peasantries and their labor remains one of the most fundamental questions of the 21 st century. In this contribution, Eric Vanhaute argues that peasants have underwritten and fueled the expansion of civilizations, empires, states, and economies for the last ten millennia, embodying what he calls "peasant frontiers." He reflects on how peasant work is foundational for resolving contemporary socio-ecological crises, including those related to capitalist industrial livestock production. The contribution is based on his new book, Peasants in World History, Routledge, 2021.
\end{abstract}

Unlike any other working and exploited class, the peasantry has always supported itself and this made it, to some degree, a class apart. In so far as it produced the necessary surplus, it was integrated into the historical economiccultural system. In so far as it supported itself, it was on the frontier of that system. (John Berger, Pig Earth, xii)

W ork, or labor, has been one of the big enigmas in historical and social sciences. It dominates human lives, human societies, and human history, but it remains hard, even impossible, to pin it down in a comprehensive definition. Jan Lucassen (2021) in his major epos on the history of work only needs one sentence, "I regard all human pursuits apart from free time or leisure as work". As Catharina Lis and Hugo Soly (2012) claim in their opus magnum, "Definitions of work are subject to dispute, since what matters in the end is who determines which efforts are worthy, i.e. meet 'socially recognized needs"'. Sociologists Charles and Chris Tilly (1998) gave us probably the most useful working definition, "Work includes any human effort adding use value to goods and services." They continue with what has become a truism in global labor history, "Prior to the twentieth century, a vast majority of the world's workers performed the bulk of their work in other settings than salaried jobs as we know them today. Even today, over the world as a whole, most work takes place outside of regular jobs."

This applies, of course, to the majority of household-based and household-related work, most of which is undertaken by women without a wage. It is also true for the most important social group in human history of the last ten millennia, the peasants. All successful cultures and civilizations the world has seen, with the famous exception of the nomadic empires, have been built on extensive peasant economies comprising 90 percent or more of the population. Still today, according to the Food and Agriculture Organization of the United Nations, around 1.3 billion people are employed in agriculture, 97 percent of them in the Global South. In general, 2.5 billion people, one-third of the world population, derive their livelihood from agriculture. They live and work on more than 600 million farms, of which more than 90 percent are family-run. Family farms remain responsible for most of the world's agricultural and food production; it is 
estimated that they produce more than 80 percent of the world's food in value terms. A significant majority of these family farms, about 500 million, are peasant holdings smaller than two hectares, six out of ten of them located in China and India. While the number of farms continues to rise globally, the average farm size has shrunk significantly. Available data show that the number and the share of female workers in agriculture is rising. Still, female farmers tend to control less land and livestock, are less likely to use credit or insurance and have lower education levels.

Writing a peasant history is writing a history of peasant work. The United Nations Declaration on the Rights of Peasants and Other People Working in Rural Areas, adopted in 2018, defines a peasant as "any person who engages or who seeks to engage, alone, or in association with others or as a community, in small-scale agricultural production for subsistence and/or for the market, and who relies significantly, though not necessarily exclusively, on family or household labor and other non-monetized ways of organizing labor, and who has a special dependency on and attachment to the land." Throughout their history, peasants have been workers of the land. They live in rural, agricultural households and have direct access to the land they work, either as common users, tenants, or smallholders. They are organized in family bonds, village communities and social groups that we call peasantries.

These bonds pool different forms of income and meet a significant portion of their subsistence needs via networks of production, exchange, credit, and protection. Most of the time, peasantries have been ruled by other social groups that extract a surplus either via rents, market transfers or through control of public power (taxation). The minimum social conditions of peasant work include access to land, labor, tools, and seeds. Historically, the principal social units through which the means of farming have been secured are the rural household and the village household system, both varying greatly in size, composition and social relations through time and space.

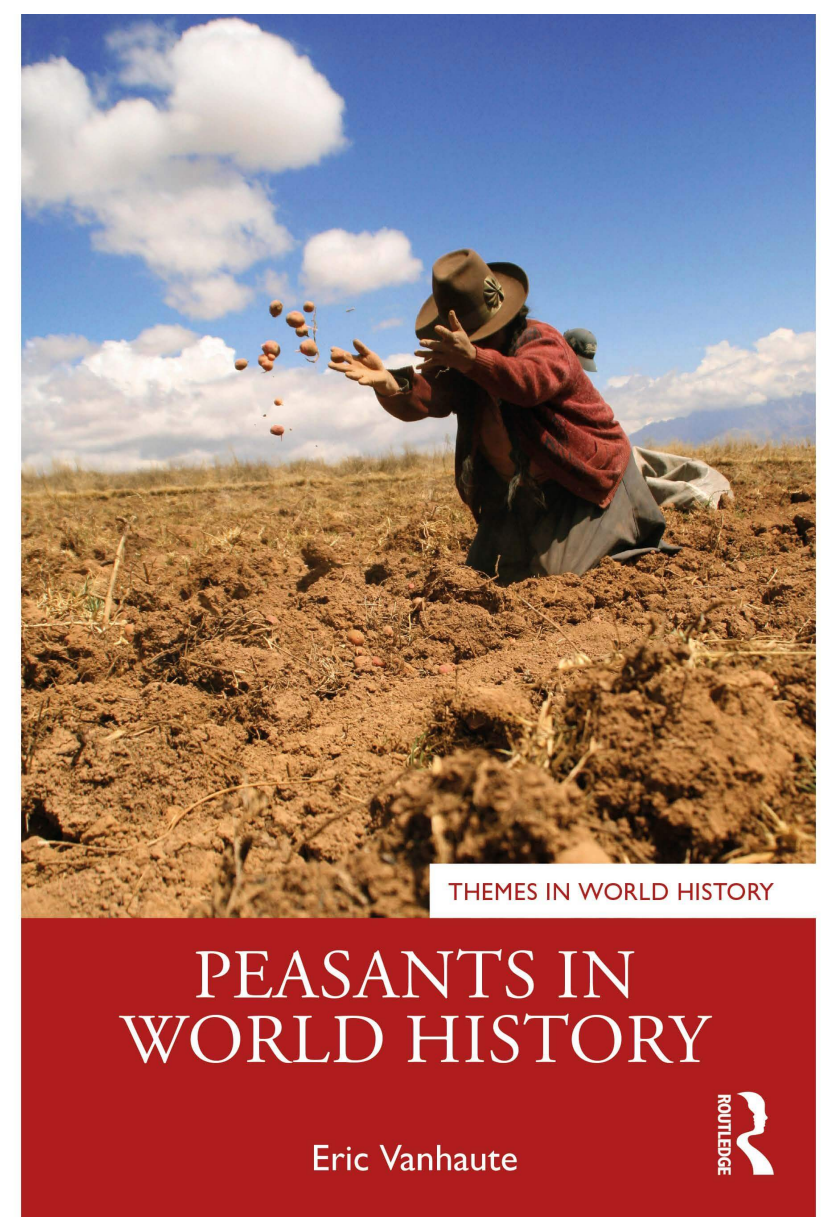

\section{History of Peasant Work}

Peasantries made societies and societies made peasantries. Surplus production from nature and the land, in various forms, has been a precondition for large-scale societal change. Societal change was necessary to group agricultural producers into peasantries. Agricultural-based economic systems facilitated vaster communal units and extended village networks. This provoked profound changes in the structure of social relations, population growth and village and supra-village institutions. The spread of agricultural village societies as the primary food system took millennia. By 5000 BCE, much of the world's population lived by farming; the first agricultural-based empires emerged by 3000 BCE. By then peasant economies had become sufficiently advanced and, in some regions, they supported more complex, urban-based societies and differentiated trade networks. Civilizations did not simply rely on agricultural producers; they also organized, dominated, and exploited 
them. Civilization equated complexity, sophistication, development, and grand culture. For peasants, it mostly corresponded to dominion. Sometimes formally free, mostly bound to the soil by their masters, they have almost always been the lowest class or caste, and women, in general, the lowest status among farmers.

The history of peasant work is the history of the struggle for the fruits of their labor. Social relations in agricultural societies have been built on the returns of the land. They were reproduced in institutions and norms that defined new rules of ownership, inheritance, transmission, and control. Peasantries did not only feed civilizations, empires, states, and economies; they also supported their ecological and social resilience and fueled their expansion. They were their socio-ecological frontiers.

Farming societies developed a new, more intrusive and aggressive attitude towards the resources of nature, land and labor. The expansion of plant and animal husbandry presumed the more radical exploitation of diverse ecosystems and the development of new tools, new modes of reclaiming lands and renewing fertility, and new modes of cultivation and animal breeding. This had an increasing impact on human-nature relations, predominantly resulting in massive worldwide deforestation. The history of peasants cannot be understood outside the societal systems that incorporated and generated them. Peasants develop strategies for survival and resistance in response to the expanding impact of state power, market relations, class struggles and ethnocultural identity conflicts. Over time, the scales upon which these social power relations are expressed have not only widened and multiplied, they have also become increasingly interdependent. The notion of peasant frontiers emphasizes that this incorporation has always been partial and that their history has never been linear. Frontiers map processes of incorporation, adaptation, and opposition. Frontiers help us understand and explain the different strategies that peasant populations have developed to defend and secure access to their essential means of production - nature, land, and labor - throughout history.
To gain a comparative-historical understanding of peasantries, we work with a gradual continuum: from strong to weak subsistence regimes and from weak to strong market-oriented regimes. This avoids fixed categories and a prescribed historical trajectory. Subsistence farming and market production have never been exclusive and, in many cases, were mutually supporting. Nonetheless, we can discern some basic types of peasant regimes by taking common access and land use rights as a central variable. Household-oriented peasant regimes were frequently supported by common land use arrangements. Family holdings, communal management and collaboration between farms were a central feature in this type of regime. The advantages were multiple: the sharing of scarce capital, minimizing income differences, guaranteeing family subsistence, mutual support, protection from external threats and overexploitation and a high degree of village autonomy. In another set of regimes, household-oriented peasant farming was only marginally supported by common land use rights or not at all. This increased the pressure on peasant survival systems and households were pushed to adopt market strategies and more land-intensive production methods. Peasant land and commodity markets became more prominent, generating a stronger differentiation between peasants.

As land use intensified, so did the input of labor to activities like weeding, crop rotation and manuring. Higher land yields came at the expense of working harder, which often negatively impacted labor productivity. Without the commons as a credit and insurance system, new credit relations were forged, often between smaller and larger farms. This resulted in intense but often unequal credit and exchange relations within and between villages. Excess peasant labor was traded for capital inputs such as horsepower, plowing and transport. This type of peasant regime, which combined subsistence and commercial aspects, emerged in many world regions and proved to be very resilient over a long time. This mixed peasant economy is often misperceived; it was not a transitionary step to full commercial farming, agricultural specialization and finally, agroindustrial family holdings. This capitalist transformation was not the final stage of advancing peasant commercialization. On the 
contrary, it was the outcome of the total metamorphosis or dissolution of peasantries. Within capitalism, peasant regimes became premised on new forms of enclosure of land and labor. Direct incorporation thoroughly altered ecological relations, resulting in a greater diversification of systems of access to nature, land and labor, systems of production and reproduction, and survival and coping mechanisms. Uneven incorporation and uneven commodification caused more social and spatial differentiation through divergent processes of de-peasantization and repeasantization, and a concurrent diversification of peasant livelihoods.

\section{Future for Peasant Work}

The neoliberal regime since the 1970's thoroughly rephrased the world-historical position of peasantries, giving a new meaning to the 'old' peasant question. Peasant communities were weakened by the expansion of transnational financial capital, an expanding rural exodus, the further proletarianization of human labor and the steady erosion of public and common domains. This happened without the expelled workforce being absorbed in industrial employment, as was supposed to occur in a classic agrarian transition to capitalism. Peasantries in the Global South were marginalized while national industries slumped. This created a massive precarious workforce that was structurally underemployed and constantly moving between towns and the countryside and across international borders. This phenomenon is often regarded as proof of the disappearance of the peasantry. But starting in the 1990s, rural protest movements proliferated around the world. They claimed peasant identity, recuperated land by means of mass occupations and protested against the destruction of their livelihoods. This partly explains why peasant mobilizations increasingly aligned with indigenous, feminist, and environmental movements.

In a contemporary context, so-called depeasantization has to be understood as a multi-layered process that erodes an agrarian way of life. This has triggered a further diversification of rural coping mechanisms, including petty commodity production, rural wage labor, seasonal migration, subcontracting to national and multinational corporations, self-employment, remittances, and transregional and transnational income transfers. Moreover, regional trends can be very adverse. Processes of de-agrarianization in core zones often coincide with the creation of new peasantries in peripheries. Recent moves towards de-agrarianization are triggered by the enforcement of neo-liberal policies and Structural Adjustment Plans. In many peripheries, vulnerability has switched from a temporary to a structural state of being. This is countered by the intensification of old and the introduction of new forms of livelihood diversification, such as taking up non-farm activities and relying on non-farm income transfers. Capitalist expansion induced a remarkable variety of labor regimes and diverse systems of recruiting, organizing, and reproducing labor. Most regimes combined subsistence with commodity production, and boundaries between labor systems remained flexible. This is especially clear from a household perspective since a large majority of households have never been solely dependent on one (wage) labor income. Non-wage labor has been an essential part of capitalism because it guarantees human reproduction and absorbs part of the costs of protection and care. In general, peasant strategies related to work and income have been geared towards self-organizing systems of land-holding and labor organization.

One solution to the contemporary peasant question might be the modernization of agriculture in the Global South by reproducing the North American and Western European model of commercial family farming. The first essential step would be to eliminate the mass of small peasant holdings and to capitalize the remaining farms. This model was made possible in the West by cheap fossil energy and agricultural chemical inputs that substituted human labor, animal traction and organic manures. The next step would be to simplify agroecosystems to the demands of mechanization and commercialization. The basic criterion to measure agriculture's efficiency would be a decline in the ratio of human labor input to production output, resulting in increased labor productivity. This reform of the countryside could then support much larger 
non-agricultural populations. Highly capitalized agriculture combined with the deagrarianization of society would come at very high costs. This type of growth systematically generates additional ecological, energetic, and social costs in the form of soil exhaustion, water pollution, biodiversity loss and social unsustainability. In many parts of the Global South, the peasantry will be rendered essentially redundant. Because this peasantry is located overwhelmingly in the Global South, this has become the prime locus of the contemporary peasant question. The peasant way, therefore, has become both a social and ecological imperative.

Twenty-first-century agriculture may not need peasants, but the world does. It has become clear that contemporary society has to embrace the peasant way, if not by choice, then by necessity. We can imagine a future peasant way by reflecting on peasant history. Polyculture and mixed farming have been the essence of peasant cultivation. Contemporary agroecological knowledge starts from the peasant's vast knowledge of soils, plants, organisms, weather patterns and microclimates. This makes contemporary peasant farming more environmentally resilient by producing a surplus, recycling nutrients and conserving water and resources. Peasant cropping primarily uses animal manures, legumes, and cover crops to provide nutrients. Agricultural efficiency is reconceptualized by expanding productivity from specific crop yields to net output per unit area. Peasant farms tend to utilize their space more intensively; they employ cropping patterns that integrate complementary plant species and small livestock populations. The ability to conserve, renew and enhance soil fertility is a prime goal of peasant farm management, drawing on knowledge passed down through generations. Contemporary methods of lower-input and labor-centered yield intensification do not return to tradition and do not reject modern science. Conversely, promoting new peasant farming methods requires much more scientific research and training to understand better how these agroecosystems operate. Complexity underpins resilience and sustainability. Throughout history, peasant frontiers and the dialectics between integration and independence created a large variety of farming systems predicated on differential forms of access to nature, land, and labor. This has always opposed the trends of simplifying and industrializing farming that increased dependence on interlocking inputs such as agricultural chemicals, seeds, fertilizers, and livestock pharmaceuticals and on privatizing scientific knowledge.

The choice for a peasant way is not only about farming and producing; it is about living together and making sense of life. For most of its history, farming was essentially localized with regard to production, the pooling of labor and the external provision of goods and services. For centuries now, capital has acted against the fundamentals of peasant farming; it has counteracted the public domain and common access and land use rights. It sought to privatize all forms of public ownership and to subjugate the power of public decisions to the needs of the market. Notwithstanding centuries of capitalist expansion and decades of neoliberal privatization and deregulation, large parts of the world's peasantries still follow a community rather than a private market logic. Private land acquisitions by speculators and producers of agrofuels have given rise to widespread resistance, often re-establishing the commons as a means of resisting the agro-industrial system.

The peasant way will integrate the peasantry's knowledge about the diversity of nature and the complexity of farming and by renewing fertility and reducing ecological and social risks. Risks and costs will be an integral part of production and exchange, and efficiency will be measured in relation to nature and land. We will rethink resilience as both a communal and a global characteristic, integrating the virtues of flexibility, cooperation, reciprocity, risk spreading and dealing with uncertainty. Peasants make use of complex landscapes, deploy diverse technologies, and build multiple social relations and networks within highly variable environments. We will redefine market relations as embedded in local societies and organized around the principles of parity. We will rethink the relation between social groups and public power. Governments and states provide protection, infrastructure, education, social services, and the arrangements to secure access to land and natural resources. We will rethink peasantries as counter- 
movements and counter-narratives, underscoring the moral claims of a diverse set of rights: rights to access land, rights to be peasants, rights to keep the cultural identity, rights to receive a just price and to work for a just income. This will also underscore the moral claims of control of access and production of food, as well as the moral claims of protection by public authorities.

Peasantization includes the rise of indigenous, ecological, and feminist consciousness, further delegitimizing capitalist modernism and resisting full proletarianization. It encompasses a moral ecological discourse, as returning to the land is claimed as a right, and converting financial capital to natural and agroecological capital is seen as a necessity. Re-peasantization bears the promise of ultimately generating more work and enhanced levels of income and self-respect. It is clear that the peasant question is not solved yet. It will remain one of the most fundamental questions of the twenty-first century.

\section{References}

Berger, J. (1979). Pig Earth. Pantheon.

Bernstein, H. (2010). Class Dynamics of Agrarian Change. Fernwood.

FAOSTAT Database [http://faostat.fao.org].

Lis, C. and H. Soly. (2012). Worthy Efforts. Attitudes to Work and Workers in Pre-Industrial Europe. Brill.

Lucassen, J. (2021). The Story of Work. A New History of Humankind. Yale University Press.

Shanin,T. (1987). Peasants and Peasant Societies. Selected Readings. Basil Blackwell.

Tilly, C. and C. Tilly (1998). Work under Capitalism. Westview Press.

United Nations Declaration on the Rights of Peasants and Other People Working in Rural Areas, Resolution adopted by the Human Rights Council on 28 September 2018.

Wolf, E.R. (1966). Peasants. Prentice-Hall.

* This text is based on Eric Vanhaute, Peasants in World History, Routledge, 2021.

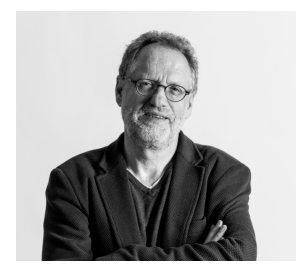

Eric Vanhaute is Professor of Economic and Social History, and World History at Ghent University.

\section{Correspondence:}

Eric Vanhaute, eric.vanhaute@ugent.be.

\section{Cite this article:}

Vanhaute, E. (2021). "Peasant Frontiers and the Enigma of Peasant Work." Commodity Frontiers 3: 51-56. doi: $10.18174 /$ cf.2021a18163.

Commodity Frontiers is an open-access journal edited by the CFI Editorial Board, Mindi Schneider, senior editor. Read it online at Commodity Frontiers, or our website, commodityfrontiers.com.

This work is licensed under a Creative Commons Attribution-NonCommercial 4.0 International License 